\title{
THE UNKNOWABILITY AND THE INEFFABILITY OF GOD ACCORDING TO JOHN SCOTT (ERIUGENA)
}

\begin{abstract}
The paper explores the negative theology employed in John (Scott) Eriugena's work "On the division of nature" as a core structure in his ontological system. Apophatic stances are crucial in Eriugena's exposition of the position and role of God, and thus in the intricate functioning of the four divisions of nature and his concept of the five modes of interpretation of being. The basic categories in his system of nature are shown, along with the most poignant claims of the ineffability and unknowability of God, in order to then analyse his framework of kataphatic and apophatic theologies in approaching the inaccessible, super-essential, incomprehensible nature of the divinity. Eriugena's opinions on the values and workings of the two branches of theology place them not in conflict or disagreement with one another, but as complementary and in constant harmony. A major part of the paper deals with Eriugena's preference for the negations of the apophatic theology when talking about God, paired with an obvious awareness that the merits of the kataphatic theology are also substantial in expressing a trace of God as a manifestation in the created world; as well as with his dialectical manoeuvre of stressing the significance of the more-than formulateons for God's super-essentiality. Therefore, Eriugena's ideas on the formulae that are affirmative in form, but negative in meaning will be overviewed, in order to show his take on the advantages of the synthesis of the kataphatic and the apophatic theologies, in the form of a "hyperphatic" theology expressing God as non-expressible (because more-than-expressible).
\end{abstract}

Keywords: ERIUGENA, GOD, APOPHATIC, KATAPHATIC, MORE-THAN, INEFFABIITY

\section{The System of the division of nature}

The dialogue Periphyseon, or De divisione naturae - On the division of nature, by the Irish philosopher John Scott (John Scottus), also known as John Eriugena (thus used further in this text), begins with two initial divisions and a definition of nature: the first and basic division of things that can either be 
grasped by the intellect, or lie beyond its reach, is a division between things that are and things that are not, and the general term for them is nature. ${ }^{1}$

Nature, as the teacher explains to the student (the dialogue is between a teacher and a student - the scholar through whom Eriugena's philosophical system is expounded, and a student who is keen to acquaint himself with the teachings), is the sum of all things that are and are not, according to the ways of existence or non-existence. The four divisions or species of nature are the following: that which creates and is uncreated (God, the One, Nothingness on account of excellence); that which creates and is created (The First, or Primal, or Primordial Causes or Forms); that which is created and does not create (the created world, the Effects of the Causes); and that which is neither created nor creates (the non-existence, Nothing through privation, 1.442A-B). ${ }^{2}$

In the explication of the structure of reality there are also the five modes of interpretation of the ways in which things can be said to be or not to be $(1.443 \mathrm{C}-1.446 \mathrm{~A}) .^{3}$ Of these modes the first seems to be that by means of

\footnotetext{
${ }^{1}$ The editions used are the ones edited by Sheldon-Williams and by Jeauneau, as well as Sheldon-William's translation; with standard pagination, in the form [Book.para$\operatorname{graph}(\mathrm{s})]$.
}

${ }^{2}$ Moran remarks that these four divisions of nature are adapted from earlier versions by Augustine and Marius Victorinus (Moran 2013, 34). In his paper on Eriugena in the Stanford Encyclopedia of Philosophy (Moran 2008) he points at a similar division in Augustine (De civitate Dei, V. 9, PL xli.151) and Marius Victorinus (Ad Candidum). In his work The Philosophy of John Scottus Eriugena: a Study of Idealism in the Middle Ages Moran analyses this in more detail. He notices that this division in this particular form cannot be found in authors before Eriugena, although there are some vague sources, like Boethius, Augustine, Bede, and Marius Victorinus. There is tripartite distinction in Augustine De civ. Dei V. 9 (PL XLI,151) between things that make (facit) and are not made (God), things that make and are unmade (the First Causes), and things that are made but do not make (the effects of the Causes). In order to transform this into a fourfold idea, Moran assumes, Eriugena must have needed to introduce the Greek idea of God as non-existence which transcends both making and having been made. Besides, Eriugena had been aware of the four types of non-existence, probably through Ad Candidum, a work that circulated in the ninth century, one manuscript of which contains marginalia by Eriugena himself (Moran 1990, 250). Moran reminds us that recent research underlines Bede's De rerum natura, which Eriugena quotes on several occasions without naming it. Bede's idea is on a fourfold nature, but differs from that of Eriugena's, and does not thoroughly list the options for the links between nature and the act of creation. Eriugena wants the division to seem logical, systematic and comprehensive, Moran explains, which is why he details the intricacies of the logical square (or the square of opposition), present in Aristotle (Moran 1990, 251; see also Sheldon-Williams, 1967, 532).

3 Things that are perceived by the senses or those in which the mind can penetrate are said to be things that exist, while those things that transcend the mind are said to be things that do not exist. Things hidden in their semina, which are not yet actuali- 
which reason convinces us that all things which fall within the perception of bodily sense or (within the grasp of) intelligence are truly and reasonably said to be, and that those which because of the excellence of their nature elude not only all sense, but also all intellect and reason are rightly said not to be. Eriugena (through the teacher) includes in this group both God and matter, and the reasons and essences of all things created by Him. The first apophatic statement is given in this preliminary exposition of the modes of being and non-being, describing God as incomprehensible.

Just as God, as he is in himself, beyond all creatures, cannot be grasped by the intellect, he is as incomprehensible when contemplated by the most inner depths of the creature that has been created by him and exists within him (1.443B-C). God is supremely incomprehensible, and Eriugena has a similar stance on the essence of the created creatures. ${ }^{4}$ God is nothing through his (incomprehensible and overwhelming) excellence. God is "nothing" in the sense that he transcends all being, he is nothing due to his superabundance, or on account of his infinity. He is so beyond-existent, that it is safe to say that he is non-existent. In any case, he is not existent in a humanly-available, created and creaturely way, but is super-essential, super-existent, non-existent. The First Causes, or praedestinationes, are the prototypes of all created essences. ${ }^{5}$ The created creatures are theophanies in the ontological system of Eriugena. ${ }^{6}$ In the nature of all created things, all the effects, is to return to their causes. ${ }^{7}$

zed, are not, do not exist, while things that have been developed from their seeds exist. The objects of intellecton can be said to exist, while the purely material objects susceptible to space, time and destruction are said not to exist. Human nature, if distant from God because of sin is said to not be, while nature which has been reconciled with God in virtue of his grace, begins to be, is said to exist (1.443B).

${ }^{4} \mathrm{~A}$ creature that is perceived through the senses or is contemplated by the intellect is known due to some quality, or quantity, or form or matter, or through some difference, or place or time, not as what it is, but merely that it is (1.443C). According to this mode, therefore, things accessible to the senses and the powers of the intellect are said to be, while those that through the excellence of their nature transcend our abilities are said no to be. This initial apophatic determination posits God as non-existent on account of his supreme transcendence.

${ }^{5}$ Similarly to Plotin's concept, they are divine ideas, but they do not exist in the Mind, but in the Logos, in the Word of God. Reminiscent to the Mind in Plotinus, they are "created" in the sense of eternal begetting of the Word (or the Son), which implies that the Primordial Causes are eternally contained in the Word as archetypal ideas (and in this sense the Logos precedes them ontologically, not temporally). The First, or Primordial Causes are paradigms, or schemes of all things, that, in a neo-platonic spirit, reside in the mind of God, and serve as immutable and eternal causes for the created creatures, which are their effects in the world.

${ }^{6}$ God manifests himself through the created nature: we get hints as to how this relation works by acquiring examples from our own nature - just as the mind is invisible 


\section{The unknowability and ineffability of God}

Everything that exists is a manifestation of the non-manifest, Eriugena claims, a manifestation of the hidden, and affirmation of the negated (which is again, an accent on the importance of via negativa), a comprehension of the incomprehensible, an utterance of the unutterable, access to the inaccessible, understanding of the unintelligible, a body of the bodiless, an essence of the supra-essential, a form of the formless, a measure of the immeasurable, a number of the unnumbered, it is weight of the weightless, a materialization of the spiritual, a place of that which has no place, time of the timeless, a definition of the uncircumscribable, a limit of the limitless (3.633B).

God reveals himself in nature, which is a true theophany. Creation is self-manifestation, in which the hidden transcendent God creates himself, by exteriorizing himself in that which proceeds from him (1.446D, pass) - in this sense, as it was mentioned, the created things are theophanies. God moves (without being physically moved, of course) from darkness into light, from self-ignorance to self-knowledge, which is, really knowledge in the form of supreme wisdom. ${ }^{8}$

Divine self-knowledge (or self-ignorance) is a problematic concept. On the one hand, Eriugena is clear about divine essence not being knowable even to creatures such as the angels $(1.447 \mathrm{C})$; and clear that the divine nature is infinite and limitless. With God being the infinity of infinities, and beyond any understanding and determination, of course that there cannot be know-

and incomprehensible, but becomes visible and comprehensible by manifesting itself through expressed words and obvious signs, so does the invisible and incomprehensible God manifest itself, so he can render himself, in a certain way, apparent and apprehensible (3.633C).

7 This process of return of all things to God implies that corporeal things will return to their incorporeal causes, temporal things will return to eternal primordial causes, the finite will return to the infinite. All things proceed from God, and all things return to God. These are not even about separate movements or processes, for they are completely complementary - one could not work without the other $(2.528 \mathrm{~A} ; 2.532 \mathrm{~A})$.

${ }^{8}$ Eriugena consistently insists in unknowability in general. He expresses a firm stance on the ignorance of the essences in the realm of non-divine cognitive subjects. Seen as no essence can be known as what it is, but merely that it is, creatures that are not God do not have true knowledge about anything. The essences of the created things are hidden in the divine essence (in the Primordial Causes), and of them it is known only according to their specific accidencies, their circumstances, in which the unknowable essence is shrouded. With the help of the application of the ten categories, the mind knows that the essences exist, but does not know what they are (1.487A-B). If it is assumed that all things participate in the divine essence, and no creature exists outside of God, then, no creature is truly knowable. The created world is something of an attribute of God, in the sense that it is God's extension or expression, through which knowledge that the divine essence exists is attained. 
ledge about him by all the types of existence that are not God (or are not God in the full sense of God as super-being). On the other hand, God is all existence, which creates a new problem, for it is unlikely that God, a superessential super-existence, does not have knowledge about the things below him. And yet, in the tractate De Praedestinatione, as well on a few occasions in On the division of nature, which are not the topic of the present paper, it is stated that God has does not know evil, for example. ${ }^{9}$

The divine essence, by being uncreated, cannot be defined by anyone, not even itself (2.586B-587B-C; 2.589B). ${ }^{10}$

9 The simplest options are the following. If God has no knowledge of the created world, but does have knowledge of infinity and limitlessness, then, it can be assumed that he has knowledge of himself. Still, it is questionable how he would not have knowledge of the nature, which is an exteriorization of himself, and would have knowledge of his infinite, limitless, indefinable nature. If it is assumed that God has knowledge about everything under the super-essential nature, but not about himself beyond the created world, this implies the infinity of infinities, which makes the created world incomparably small, so it can be claimed that in the grand scheme of things, he does not have knowledge of himself.

The concept of the divine self-ignorance seems in conflict with the traditional understanding of God as omniscient, and with that, it seems to be an exaggerated consequence of the negative theology. The opinion that God cannot know himself is characteristic of Plotinus, for example, inspired by the criticism of Aristotle's concept of God as a self-thinking thought. The One in Plotinus is completely simple and unified, it contains no plurality, no duality. This means that, should there be a thought and someone to think that thought, the One would be both a subject and an object, it would contain duality, which is contrary to its absolute unity (Enn. 3. 8, 9).

Eriugena mentions as early as in the initial exposition of the five modes of interpretation, and many times throughout the books, that it cannot be known what God is, for the essence of things, their "what-ness" cannot be known, that what can be known is merely that they are. If God knows himself, he is then an object, a "what" that could be defined, a "what" with a limit and determination. By not being a "what", not having any attributes through which he could be defined, God is infinite and indefinable (1.470C-474C; 1.482C-483C; 2.586B-C; 2.589B-C; 2.590). If God could define himself, he would be inaccessible, incomprehensible and ineffable to the created creatures, but not to himself, and so he would no longer be supremely incomprehensible and infinite.

${ }^{10}$ It seems that Eriugena brings apophasis to a limit: because it cannot be known what a thing is, but just that it is, the human mind cannot know God; the essences of the things remain unknown, and God does not know himself, nor does he know the created essences of the creatures. Ignorance is supreme wisdom, according to Eriugena, and this saves this entire construct of general ignorance. God is known better when he is not known; the divine nature is better understood when everything of it is denied. In a similar manner, the divine ignorance of himself is an understanding that he is nothing of the created things, and that he is the infinity of infinities. God's ignorance is an ineffable wisdom - God knows he is more than all things, beyond all things, above existence (3.590B-D; 593C-D; 2.594A; 2.596D; 2.598A). 
The kataphatic and the apophatic approach and the "hyperphatic" synthesis

A vast part of Eriugena's efforts are directed towards the illumination of the conceptions of the divine transcendence and immanence, similarity and complete difference, hiddenness and revelation, that is, the ways in which the divine essence, incomprehensible and ineffable in itself, can be understood and expressed in its exteriorization in the created world.

Definition is possible only if it refers to the created effects, to when something has started to exist. ${ }^{11}$ Definition is of the "what-ness" of a thing, it focuses on its limits, its completeness. Therefore, the human mind is capable of knowing things about the created world - these are differentiated creatures possessing quantity, quality, relation, condition, spatio-temporal localization etc., they are definable things, of which knowledge is gained through their circumstances, the accidencies and the attributes that clearly characterize them, giving them their "what-ness", encapsulating the hidden essences.

The knowledge that God is gets attained only through the things created by him, but it cannot be concluded what he is through the existence of the creatures. Therefore, the only definition applicable to God is that He is Who is more-than-being (1.487A-B). ${ }^{12}$ God is, as it was mentioned multiple

The "hyperphatic" formulae (God is more-than-created things) lead to a knowledge that is simultaneously knowledge and ignorance, knowledge that, not what and who. It is a form of unknowing knowledge that cannot be explained in the language of the created nature, and finally, it is an ineffable mystery (5.976C) of the infinite super-essential beyond-Being.

${ }_{11}$ Carabine identifies a "very Plotinian way" in the description of the process: the form is the measure that imposes itself onto the unformed matter, which places it within the realm of limitation, and with that, definition (referring to 2.590A-B, Carabine 1995, 304).

12 Nothing is more hidden than God, and nothing is more present; it is difficult to say where he is, even more difficult to determine where he is not, Eriugena explains, he is an ineffable light perpetually present for the intellectual eyes of everyone, and yet unknown to all intellects. God is distributed through all of the things in the infinity; he is all things in all things, and nothing in nothing (3.668C-D).

Sells remarks that to consider what it is not, to consider the divine as nothing, means to consider that which is even beyond the dialectical reasoning of Eriugena. The concept of the nothingness of the divine implies a concept of reality as infinite, and of theophany as a manifestation out of the abyss of existence (Sells, 1994, 60). The mystery of being, of life, and of consciousness is impenetrable - no mind, not even the mind of the divine, can fully understand these mysteries, for not even God can know God. Reason is guided by its own reasoning beyond itself, constantly and relentlessly, but without ever reaching any final entity or a conclusion. In this particular sense of allowing reason to be guided by itself outside of itself, Eriugena can be considered a mystic, Sells reckons (Ibid.). 
times, super-essential (or rather, he is "super-essentiality", 1.459D), he is so over and above essence, that he is non-essential - in this sense this is another indicator of the deep-rooted inclination towards the apophatic approach in Eriugena's ontology.

Similarly to other apophatic approaches, a major problem in Eriugena is the attempt to talk of the untalkable; the attempt to explain that we should not talk of the ineffable, and list all the ways in which we should not talk. Besides, a belief in Eriugena is apparent, likely inspired by Pseudo-Dionysius, that theological language is not completely detached from a certain objective foundation (see Beierwaltes, 1984, 523-543). Similarly to the rest of the apophatic approaches typical for the theological positions of a combined supreme transcendence and some sort of immanence of God, there is an attempt in Eriugena at a clear formulation of the stance that language fails, but not entirely, in describing the reality which is simultaneously transcendent and indescribable, yet immanent enough to let at least some of its aspects be known.

According to Eriugena (and following a long established tradition among the Platonists and Neo-Platonists), Aristotle's categories work for describing the created world and cannot be applicable to God (1.463D), for whom it cannot be literally (properly, proprie) said that he is substance or essence (ousia, essentia), nor can he described through quality, quantity, relation and in terms of spatio-temporality. ${ }^{13}$

Eriugena pays attention to an explicit outline of the approaches to God, aware of the advantages and the challenges of both kataphatic and apophatic theology. We should either be completely silent, he stresses, admitting that God surpasses and intellect, residing in an inaccessible light, or, if he were to be discussed, explore the many ways and various arguments of both of the branches of theology, kataphatic and apophatic (1.458A). The kataphatic theology predicates the things that are to the divine essence, without equating it with them, but rather by showing how their existence stems from God (1.458B). The kataphatic theology posits all of the things that are as predicates of God, which is why it is considered to be affirmative - not because it claims that God is any of the things that are, but because it sustains that all things get their existence from God and can be attributed to him. The teacher explains that in the apophatic theology, on the contrary, we deny that the divine essence or substance is any of the things that are, things that can be talked about, understood. Eriugena underlines multiple times that names and terms that are predicated of God through affirmation are done so in a purely metaphorical sense (1.458A-C; $1.453 \mathrm{~B} ; 1.458 \mathrm{C} ; 1.460 \mathrm{C} ; 1.463 \mathrm{~B}$;

${ }^{13}$ Carabine notices that the analysis of the categories in regards to the divine essence is not merely a logical exercise, but it provides us with the key to understanding on how to properly interpret all that which is said of God in the five books of the work (Carabine 2000, 32). 
$1.512 \mathrm{~B}$, etc.), and warns against any misconceptions that could arise out of the misunderstanding of this distinction. ${ }^{14}$

Things that are opposed are in such a relation, that both commence at the same time, and cease to be the same time, independently on whether they are of the same nature (like the single and the dual), or of different natures (like light and darkness), or in terms of privation (like life and death, sound and silence), which is to be expected from things susceptible to generation and destruction; and that which is in disharmony (one with the other) cannot be eternal. Should they be eternal, there would not be a way through which they would be in disharmony with one another, for eternity is always as it is, and it perpetually exists in itself as single and indivisible unity (1.459B). The teacher is trying, as it were, to show that nothing which has opposition can be suitably attributed to God. God is called Essence, but strictly speaking, is not essence, because inexistence is opposed to existence. Thus, it would be correct and suitable to consider God super-essential (or even better, super-essentiality). God is called Goodness, but he is not goodness, because evil is opposed to it. Accordingly, he is more-than-good, or more-than-goodness (1.459D). He is called God, but strictly speaking, he is not God. ${ }^{15}$ Since God cannot be seen, perceived, understood, in the ways that

${ }^{14}$ The attributes of the created nature can be applied to God, and about him it can be talked, always keeping in mind that is it a simple transposition of affirmations suitable for the created nature on the super-essential overwhelming divine nature, for which they are clearly unsuitable. Affirmations do have a dose of validity, of course, in speaking of the inaccessible divine essence, for they cover its nudity with a shroud available to the human mind. A part of the truth, a trace of the truth for the divine essence is represented within the kataphatic theology as partially available for the limited human mind. Negations are not predicated to God metaphorically, but literally, and because of this they carry more strength in denoting the ineffable essence such as it is in itself.

We constantly see Eriugena relentlessly struggle with his own concept of God in order to show the correct interpretation of the divine reality, making sure he does not wander too far into the field of affirmative theology, nor rely too heavily on the negative theology, Sells remarks. The methodology of negative theology permeates the entirety of Eriugena's thought: anything that can be said of God can be contradicted, and even that contradiction can be contradicted. God is nothing; God is something; God is not nothing; God is not something - summarizes Sells (Sells, 1994, 59).

${ }^{15}$ Carabine feels that, strictly speaking, although all terms are discarded, the divine essence can still be denoted by these more-than formulations (Carabine 1990, 312-313). Still, this is hardly consistent with the apophatic approach in Eriugena. A negation of an attribute in the "more-than-(noun/pronoun)" construction does not denote the essence of God, because, firstly, Eriugena himself claims that although the form of the more-than formulations is affirmative (and affirmations, as it was mentioned, carry parts or hints of the truth), their meaning is negative (negations are suitably applied to that which cannot be denoted). More-than-X cannot, strictly speaking, denote anything of the divine essence, because the accent, like in all of the apophaticists who use 
he is, it is better to say that he is more-than-God. ${ }^{16}$ The more-than formulae mark the unknowability of the divine nature, on account of his infinite transcendent super-essentiality - language guides us only to the knowledge that he cannot be known, and leaves the attributes unconceivable and ineffable to us to be uncontainable in the thoughts and linguistic constructs. The kataphatic form of the apophatic meaning yields a hyperphatic position, one which encompasses parts from both the positive and the negative theology, and surpasses both - it linguistically points to the failure of language. Language is an expression of a metaphysical reality, because of the existence of the created world as Effects of the Primordial Causes, and a self-manifestation of God, yet it is completely powerless to express the inexpressible, due to its unthinkable, unconceivable nature which cannot be limited within definitions and determined by human-formulated characteristics. ${ }^{17}$

these types of constructions is not on the fact that something is being said about God/Being/the One, but on the fact that whatever is being said, fails at comprehending the over-abundance of the superior instance in question.

If it is taken into consideration that negations apply literally to the divine super-essence, as Eriugena claims, then it can safely be assumed that what is meant by the more-than formulae is that God is more-than- $X$, which effectively deconstructs his ineffability. However, when Eriugena claims that negations are litterly applied to God, he refers to the pure linguistic negative forms, not the more-than-X affirmations with negative meaning. More-than means exactly that - some hyperbolized, transcendent, inaccessible, unavailable attribute, so far beyond our cognitive abilities, that we cannot even conceptualize the extent of the "more", or the attribute that we are trying to determine.

${ }^{16}$ According to the same principle, he is not Truth, to which lies are opposed, but is more-than-true and more-than-truth. The same procedure can be applied to all of the divine names. God cannot be properly Eternity, for temporality is opposed to it, which is why God is more-than-eternal and more-than-eternity. Nor wisdom can be predicated of God, for the stupid and foolish are opposed to the wise ones and to wisdom, which makes God more-than-wise and more-than-wisdom. Similarly, he is not life, to which death is opposed, and so on (1.460B).

${ }_{17}$ Language contains the symbols that point towards the divine; consequently the created creatures, as corporeal expressions of the incorporeal, are found in the affirmative statements of negative theology. The words which are used to attempt to describe and communicate the nature of the divine super-essentiality in a human-available and clear form are found at a triple distance from the reality they are trying to express - language is a verbal expression of a corporeal manifestation of the incorporeal (Beierwaltes 1984; Carabine 1990, 314-315). On the influences on Eriugena concerning the theories of language in On the Division of Nature (St. Augustine, St. Anselm, Pseudo-Dionysius), see Moran 1996, 240-260.

As it was mentioned, according to Sells, to understand God as the basis of reality in terms of nothing, means that lacking a final entity or a conclusion towards which language would strive, it is in eternal movement (Sells, 1994, 59). This does not mean that language, a verbal manifestation of the corporeal manifestation of the incorpore- 
If the terms from the more-than formulations are applied literally to the divine essence, and it is allowed that this undermines the concept of his ineffability, then a question about the substantiality of the apophatic approach arises. In Eriugena, ample preemptive solutions about this possibility for interpretation are found, because he is perfectly aware of the possible emergence of this problem. This is why the student explicitly asks whether, since the more-than formulations are literally applied to God, it would no longer mean that he is ineffable ("... if in any way of something can be spoken, it is not ineffable"), for which the teacher lauds his precaution (1.461A). The concept of language inspired by Gregory of Nyssa distinguishes between an exterior sense of the word, and an interior sense, through which the object is being denoted by the exterior form. ${ }^{18}$

Eriugena insists on the fact that, although seemingly opposed, between affirmation and negation (at least when it concerns the types on theology, as he does not generalize this opinion to the entirety of logic), there is no exclusive disjunction when they are applied to the divine nature, on the contrary, they are in harmony in every way and in every sense (1.461C). So, for example, kataphatically it is said "he is Truth", and apophatically "he is not Truth", and it might seem that there is a contradiction, while there is no conflict whatsoever. The one that claims "it is Truth", does not affirm that the Divine Substance is Truth, but that it can be called by such a name, transfer-

al, becomes meaningless due to the negation - it is clear in Eriugena that the created world is a manifestation of God, who "speaks" the causes for all of the things in the Word; the proceeding of the things from God expands also to the exteriorization in the form of human speech as an effect. When something of God is being negated, it does not mean that God is not concretely that thing or that he is nothing (in relation to that thing), but that God is the nothingness which (paradoxically) is everything. Negations about God are not empty statements, but rather they carry in them the ontological position of the nothing-everything overlap.

Carabine summarizes that the insistence with which Eriugena reexamines language, casting doubts on the linguistic and cognitive processes, means that he leads both word and thought to the precipice of their meaning, before the next negation casts them into a new vortex of meaning, which will then be subject to a new further transformation (Carabine 2000, 63).

18 The distinction between the affirmative form and the negative meaning, the fact that through more-than- $X$ it is even more strongly stressed that it cannot be known

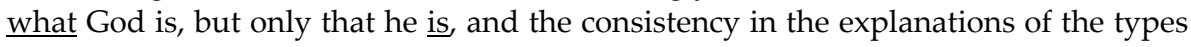
of theology are all in favor of the irrefutability of the apophatic conception of Eriugena's. If of God is in any way talked, he is obviously not ineffable (1.460D-461A). Strictly speaking, to the ineffable Nature no verbs, nouns, or any signs whatsoever can be applied - not literally, but metaphorically is God called Essence, Truth, Wisdom and all the other similar names, while it being better that he should be called super-essential, super-true, and super-wise (1.460C). This is why the different approaches of the apophatic and the kataphatic theology exist. 
ring meaning from the created to the Creator, for the Divine Essence (or rather, Super-essence), stripped of every suitable denotation, must the shrouded by such appellations (1.461D). On the other hand, the one that claims "it is not Truth" clearly understands, as it is right, that the Divine Nature is incomprehensible and ineffable, and does not deny that it is (that), ${ }^{19}$ but that it can be called Truth or be Truth.

All the denotations with which affirmation (the kataphatic theology) clothes divinity are removed by negation (the apophatic theology). The former, clothing God, claims, for example, "He is Wisdom", while the latter, unclothing him, claims "He is not Wisdom", by which the former claims "he can be called like this/can be named as such", without claiming "He is exactly like this/such", and the latter claims "he is not this, although he can be called according to, or like, this" (1.462A). Affirmation and negation are found together in all the names that contain "super" or "more-than- $X$ ", which is why it cannot be clearly and distinctively determined whether such names belong to the kataphatic or to the apophatic approach. The student reaches this conclusion, albeit having started this analysis by voicing some doubts about the inclusion in the negative theology of statements and names that do not contain a negative particle (such as "no", or the alpha-privative), yet knowing that it would not do them justice to place them in the kataphatic sphere. When of something is said that it is super-essential, it cannot be understood as nothing other than negation of its essentiality - although negateon is not contained in the words, it is expressed by the words, for the hidden meaning is not really hidden from those who think properly (1.462C).

${ }^{19}$ In this example the existence of God is not being denied, although it can be negated, both along the lines of this argumentation (it has an opposition - non-existence), and according to the previously mentioned examples (God is not existence, for he is super-existent). There is nothing besides God and nothing outside of him, because all the things are in him, and outside of him there is no thing. God is infinite and morethan-infinite, because he is the infinity of infinities; simple and more-than-simple, because he is the simplicity of all the simple things. There is nothing in him, for he is the periphery of all the things that are and the things that are not, things than can be and cannot be, and that appear as contrary or contradictory to him. He is the similarity of the similar things and the dissimilarity of the dissimilar, the opposition of oppositions. All of this is possible because he gathers these things together and through a beautiful and ineffable harmony brings them together in one order of things. In this way it can be explained how things that in some parts of the universe seem opposed to each-other, or disharmonic, are actually in harmony when observed within the most general harmony of the universe itself (1.517C).

On the relation of existence and non-existence in the system of Eriugena, see Carabine 2000, 37-43, where it is analyzed through the concept of negative ontology. The chapter in The Unknown God is even titled "John Scott Eriugena: negative ontology" (Carabine 1995, 301-322). 
Names that are predicated to God by adding "super" or "more-than", purports Eriugena through the teacher, contain in them in the fullest sense both branches of theology, as they are affirmative in the form of the exterior expression, and contain the force of negation in their meaning. When it is said of God that he is not one of the things that are, but that he is more than them, in no way is it defined what that "is" means (1.462D). ${ }^{20}$

These formulations can be considered as part of the "hyperphatic" theology, which surpasses the kataphatic and the apophatic (being fond of dialectics, Eriugena can be envisioned to approve of an interpretation of this relation as thesis-antithesis-synthesis, in order to anachronistically treat the hyper-affirmations as Aufhebung of the approaches of the kataphatic and the apophatic theology; excellent indicators are the referenced paragraphs $1.459 \mathrm{C}-460 \mathrm{~B}) .^{21}$

On a linguistic level, the concept of the divine transcendence and immanence is always found - everything that is comprehended is a phenomenon of the non-appearing, a manifestation of the hidden, an affirmation of the negated; it is understanding of the unintelligible, utterance of the unutterable, access to the inaccessible, body of the bodiless, essence of the non-essential, form of the formless etc. (3.633A).

${ }^{20}$ Although the divine transcendence has priority over the immanence, and the negation is more suitable than the affirmation, Eriugena is aware of the form and contents of the super-affirmations. The formulations with "super" or "hyper-" have the form of affirmations, and the meaning of negations (although superficially affirmative, their meaning is purely negative, 1.462D).

${ }^{21}$ Eriugena is perfectly aware of the relation between the types of theology. Although his system presupposes a strong negative-theological inclination, because of his preference for apophatic statements which are more suitably true for the supreme transcendence of the divine ( $(2.539 \mathrm{C} ; 2.613 \mathrm{~A} ; 5.865 \mathrm{D}-866 \mathrm{~A})$, as it was mentioned, the concept of the created nature as theophany indubitably implies a possibility for a partial understanding of God. The tension and complementarity between the kataphatic and the apophatic theology, and the seemingly contradictory, and in reality mutually dependant concepts of the divine transcendence and immanence are connected with, or even a part of the general system of coincidence of opposites in the double nature of God. The inexplicable and ineffable nature of God is a reconciliation of all opposites, God is the opposite of opposites (1.452D-453A; 1.514D-515A; 1.517B-C). The metaphysical duality of nature consists also in the fact that God is over and under and in and outside of all things (2.590B), the measure of everything that has no measure, a number without a number and a thought without thinking, a place for the misplaced and placeless, and time of the timeless (3.533B), an unformed form of all things $(2.525 \mathrm{~A} ; 2.599 \mathrm{D}-600 \mathrm{~B} ; 2.546 \mathrm{D}-547 \mathrm{~A})$, and that which contains everything without being contained in something (else). 
In the discussion about God as the cause of all things it is clearly stated (and with self-confidence reiterated by the student) that it is "pretty impossible" to define what, or of what kind, the Cause and Nature of all things is, for that which refuses to be understood is impossible to define (1.455D; $1.460 \mathrm{C} ; 1.522 \mathrm{C})$. Eriugena does not think that the divine super-essence prohibits speech of it, he thinks that the thing that should remain hidden, will simply remain hidden and forever unknown, while people are capable of talking (or rather attempting to talk) about the divine essence, in order to teach the simpler minds, and to praise and worship God. In this sense, it can be talked about the ineffable, explain the inexplicable, as long as it is kept in mind that it is done in a purely metaphorical way, and that it is essentially unsuited (3.619C).

According to all of this, considering that the human incapability to properly describe and explain the divine essence is supplemented with the linguistic constructions suitable to encompass the divine manifestation in the created nature, it is obvious that in Eriugena's system the kataphatic and the apophatic theologies, and their "hyperphatic" synthesis are in constant interplay. 


\section{References}

Beierwaltes, W. (1984). "Sprache und Sache. Reflexionen zu Eriugenas Einschätzung von Leistung und Funktion der Sprache." Zeitschrift für philosophische Forschung 38: 523-543.

Carabine, D. (1995). The Unknown God. Louvain: Peeters Press.

Carabine, D. (2000). John Scottus Eriugena. Oxford University Press: Oxford.

John Scotus Eriugena (1968). Periphyseion (De Divisione Naturae) Liber Primus.

I. P. Sheldon-Williams, ed. Dublin: Institute for advances studies.

John Scotus Eriugena (1972). Periphyseion (De Divisione Naturae) Liber Secundus. I. P. Sheldon-Williams, ed. Dublin: Institute for advances studies.

John Scotus Eriugena (1981). Periphyseion (De Divisione Naturae) Liber Tertius. I. P. Sheldon-Williams, ed. Dublin: Institute for advances studies.

John Scotus Eriugena (1987). Periphyseon (The Division of Nature). I. P. Sheldon -Williams, tran. Montreal: Bellarmin.

John Scotus Eriugena (1995). Iohannis Scotti Eriugenae Periphyseon (De divisione Naturae) Liber Quartus. E. A. Jeauneau, J. O'Meara, eds., J. J O'Meara, I. P. Sheldon-Williams, tran. School of Celtic Studies-Dublin Institute for Advanced Studies.

Moran, D. (1990). "Pantheism from John Scottus Eriugena to Nicholas of Cusa." American Catholic Philosophical Quarterly 64, no. 1:131-151.

Moran, D. (1996). "Eriugena's Theory of Language in the Periphyseon - Exploration in the Neoplatonic Tradition." In Próinseas Ní Chatháin, M. Ricterd, eds., Ireland and Europe in the early Middle Age. Klett-Cotta, pp. 240-260.

Moran, D. (2008). “John Scottus Eriugena." E. N. Zalta, ed. The Stanford Encyclopedia of Philosophy (Fall 2008 Edition). URL=<https://plato.stanford. edu/archives/fall2008/entries/scottus-eriugena/>.Accessed on 15 April 2019

Moran, D. (2013). "Iohannes Scottus Eriugena". In G. Oppy, N. N. Trakakis, Eds., Medieval Philosophy of Religion: The History of Western Philosophy, vol. 2. Routledge: London and New York, pp. 33-45.

Ryan, H. J. (1967). The De praedestinatione of John Scottus Eriugena: An introductory study. Rome: Pontificia Universitas Gregoriana, Facultas Theologica.

Sells, M. A. (1994). Mystical Languages of the Unsaying. Chicago: Chicago University Press.

Sheldon-Williams, I. P. (1967). “The Greek Christian Platonist Tradition from the Cappadocians to Maximus and Eriugena". In A. H. Armstrong, ed., The Cambridge History of Later Greek and Early Medieval Philosophy. $1^{\text {st }}$ ed. Cambridge: Cambridge University Press, pp. 425-537. 